\title{
Anti-Tumor and Anti-Oxidant Activity of Ethanolic Extract of Epipremnum Aureum Linn. Leaves against DAL Induced Tumor in Swiss Albino Mice
}

\author{
Venkatesh S. ${ }^{1}$, Muhamed K. ${ }^{2}$, Mridhul Mohan P. ${ }^{3}$, Asheena Asharaf V.V. ${ }^{4}$, Anjitha P. ${ }^{5}$, Suresh A. ${ }^{6}$ \\ ${ }^{1}$ Assistant Professor, Department of Pharmacology, Devaki Amma Memorial College of Pharmacy, Chelembra, Malappuram, \\ Kerala, India \\ ${ }^{2,4,5}$ M. Pharm Student, Department of Pharmacology, Devaki Amma Memorial College of Pharmacy, Chelembra, Malappuram, \\ Kerala, India \\ ${ }^{3}$ Assistant Professor, Department of Pharmacology, Devaki Amma Memorial College of Pharmacy, Chelembra, Malappuram, \\ Kerala, India
}

${ }^{6}$ Professor, Department of Pharmacology, Devaki Amma Memorial College of Pharmacy, Chelembra, Malappuram, Kerala, India

\begin{abstract}
Neoplasia literally means the process of "new growth," and a new growth is called a neoplasm. The term tumor was originally applied to the swelling caused by inflammation. Neoplasms also may induce swellings, but by long precedent, the noneuplastic usage of tumor has passed into limbo; thus, the term is now equated with neoplasm. Oncology (Greek oncos $=$ tumor) is the study of tumors or neoplasm's. Cancer is the common term for all malignant tumors. The present study was designed to investigate the anti-tumor activity of ethanolic leaves extract of Epipremnum aureum Linn. and evaluated by in-vitro and in-vivo experimental models. To achieve objectives, EEEA was subjected to phytochemical screening and tested for oral toxicity test. The in-vitro study was carried out by means of MTT assay and Trypan blue dye exclusion assay using DAL cell lines. The in-vivo antitumor activity was evaluated against DAL tumour bearing mice by liquid tumour models. Preliminary phytochemical screening was confirmed the presence of flavonoids, glycosides, tannins, phenolic, steroids, and triterpeniods etc. EEEA showed good cytotoxic effect on DAL cell line in MTT assay and Trypan blue dye exclusion assay. Oral administration of EEEA in tumour bearing mice for 14 days, showed significant reduction in the percent increase in body weight, tumour volume, tumour weight, viable cell count when compared to the untreated mice of the DAL control group. The restoration of the haematological parameters towards the normal control was also observed. The results suggested that the EEEA exhibits significant anti-tumor activity towards both methods. The DAL-bearing mice orally administered leaves of Epipremnum aureum Linn., at 200 and $400 \mathrm{mg} / \mathrm{kg}$ body weight showed significant change in the average life span compared to animals of the tumor control group. The percentage increase in body weight, tumor cell volume, and number of viable tumor cells were found to be significantly less than the tumor control animals, indicating the anti-tumor nature of the extract.
\end{abstract}

KEYWORDS: Epipremnum aureum Linn., Daltons ascites lymphoma, Liquid tumour model, MTT cytotoxicity assay, Trypan blue dye exclusion assay

\section{INTRODUCTION}

Cancer is a class of diseases characterized by out-of-control cell growth. The cancer cells invade the adjacent and distant tissues via circulation. Cancer is a group of diseases in which the cells are aggressive (grow and divide without natural limits), invasive (invade and destroy adjacent tissues), and/or metastatic (spread to other locations in the body). ${ }^{1}$ The available anti-tumor drugs have distinct mechanisms of action which may vary in their effects on different types of normal and cancer cells. ${ }^{2}$ A single 'cure' for cancer has proved elusive since there is not a single type of cancer but as many as 100 different types of cancer. In addition, there are very few demonstrable biochemical differences between cancerous cells and normal cells. For this reason the effectiveness of many anticancer drugs is limited by their toxicity to normal rapidly growing cells in the intestinal and bone marrow areas. A final problem is that cancerous cells which are initially suppressed by a specific drug may develop a resistance to that drug. Higher plants, a source of medicinal compounds, have been well known to play a dominant role in the health care of human beings. ${ }^{3}$ More than $50 \%$ of all modern drugs in clinical use are of natural product origin. ${ }^{4}$ Many natural products have been recognized to have the ability to induce apotosis in various tumor cells of human origin Epipremnum aureum Linn. is a species of flowering plant of Araceae, native in 


\section{International Journal of Current Science Research and Review}

ISSN: 2581-8341

Volume 04 Issue 08 August 2021

DOI: 10.47191/ijcsrr/V4-i8-18, Impact Factor: 5.825

Mo'orea, French Polynesia. The species is a popular house plant in temperate, but has also become naturalised in tropical and subtropical forests worldwide, including northern Australia, Southeast Asia, India, Pakistan, Nepal, Bangladesh, Hawaii and West Indies, where it has caused severe ecological damage in some cases. ${ }^{\mathbf{5}}$

Epipremnum aureum Linn. possess the Anti-inflammatory, Anti-oxidant, Analgesic, Antimicrobial, Anti-termite, Anti-fungal activities.

\section{MATERIALS AND METHODS}

\section{Collection of plant}

Epipremnum aureum Linn. widely distributed in the western regions and India. Fresh plant was collected in the month of January and authenticated by A. K. Pradeep, Herbarium curator, Department of Botany, University of Calicut, Thenhipalam, Kerala, India. The specimen voucher was deposited in the Department of Botany, University of Calicut, itself. (Specimen 148207). Macrocsopical evaluation refers to the evaluation of colour, odour, taste, shape, and fracture. It is a technique of qualitative evaluation based on the study of morphological and sensory profile of the plant.

\section{Extraction}

The leaves were shade dried for one month and powder was prepared by using grinder (coarse powder). The powdered dried leaves were extracted with ethanol by using soxhlet apparatus. After extraction the solvent was evaporated and concentrated extract was obtained. ${ }^{6}$

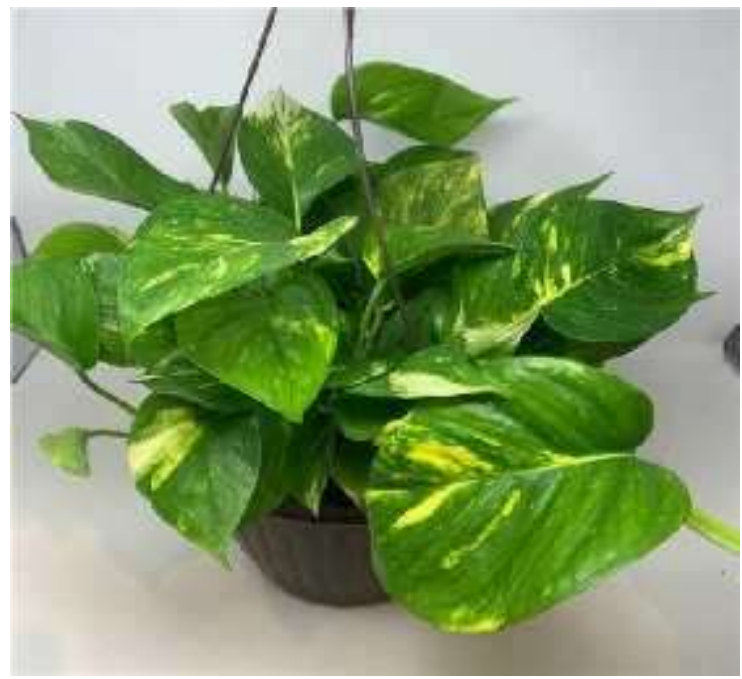

Fig 1. Epipremnum aureum Linn. Leaves

\section{Phytochemical identification test}

The EEEA was subjected to qualitative chemical tests for the detection of various plant constituents like carbohydrates, glycosides, proteins and amino acids, fixed oils and fats, gums and mucilage, alkaloids, phytosterols, flavonoids, tannins and phenolic compounds, saponins, triterpeniods, etc. ${ }^{7}$

\section{PHARMACOLOGICAL ACTIVITY}

\section{Animals}

Albino mice of Swiss strains were used for the pharmacological and toxicological activity. These animals were maintained in the animal house of Devaki Amma Memorial College of Pharmacy, Chelembra, Malappuram, Kerala, India. Female mice were selected nulliparus and non-pregnant. Female mice weighing about 25-30 g were used for the study. Each animal at the commencement of it's dosing between 8-12 weeks old and thus weight variation was within $\pm 20 \%$ of the mean weight of any previously dosed animals. The temperature in the experimental animal room was $22^{\circ} \mathrm{C}\left( \pm 3^{\circ} \mathrm{C}\right)$ and the relative humidity was between $50-60 \%$. These animals fed with pellet diet manufactured by Amrut Laboratory, Animal Fed Company, Sangli, Maharashtra and drinking water and ad 


\section{International Journal of Current Science Research and Review}

ISSN: 2581-8341

Volume 04 Issue 08 August 2021

DOI: 10.47191/ijcsrr/V4-i8-18, Impact Factor: 5.825

IJCSRR@ 2021

Www.ijcsrr.org

libitum. They were kept in 12 hours light/dark cycle and maintained for at least 5 days prior to dosing to allow for acclimatization to the laboratory condition. The animals experimental protocol has been approved by our Institutional Animal Ethics Committee (IAEC) vide registration no:

\section{DAMCOP/IAEC/022. ${ }^{8}$}

\section{Acute oral toxicity study Limit test}

The acute oral toxicity study was carried out on Swiss Albino mice as per the guidelines No: 425 given by the Organization for Economic Co- operations and Development (OECD 425, 1988). A limit test at one dose level of $2000 \mathrm{mg} / \mathrm{kg}$. body weight was carried out with six animals (Three animals per step) were fasted overnight. Animals were observed individually after dosing at least once during the first 30 minutes periodically during the first 24 hours, with special attention given during first 4 hours and daily thereafter for 14 days.

\section{In-vitro anti-tumor study}

Cytotoxicity assays are widely used by the pharmaceutical industry to screen for cytotoxicity in libraries. Researchers can either look for cytotoxic compounds, if they are interested in developing a therapeutic that targets rapidly dividing cancer cells. Assessing cell membrane integrity is one of the most common ways to measures, cell viability and cytotoxic effects. Vital dyes, such as trypan blue or propidium iodide are normally excluded from inside of healthy cells; however, if the cell membrane has been compromised, intracellular components. ${ }^{9}$ This assays measures the reducing potential of the cell using a colorimetric reaction. Viable cells will reduce the MTS reagent to a coloured formazan product. The MTT assay and Trypan blue dye exclusion method were employed for assessing the cytotoxicity of the plant Epipremnum aureum Linn. ${ }^{10}$

The colorimetric assay is based on the capacity of mitochondria succinate dehydrogenase enzymes in living cells to reduce the yellow water soluble substrate 3-(4, 5-dimethylthiazole2-yl)-2, 5-diphenyl tetrazoliumbromide (MTT) in to an insoluble, coloured formazan product which is measured spectrophotometrically. Since reduction of MTT can only occur innmetabolically active cells, the level of activity is a measures of the viability of the cells.

MTT [3-(4, 5-dimethylthiazole-2-yl)-2, 5-diphenyl tetrazolium bromide] is a pale yellow substrate that is cleaved by living cells to yield a dark blue formazan product. This process requires active mitochondria, and even freshly dead cells do not cleave significant amount of MTT. Thus the amount of MTT cleaved is directly propotional to the number of viable cells present, which is qualified by colorimetric methods. Briefly, the compounds were dissolved in DMSO and serially diluted with complete medium to get the concentration a range of test concentration. DMSO concentration was kept $<0.1 \%$ in all the samples. Cell line maintained in appropriate conditions were seeded in 96 well plates and treated with different concentration of the test samples, and incubated at $37^{\circ} \mathrm{C}, 5 \% \mathrm{CO}_{2}$ for 96 hours. MTT reagent was added to the wells and incubated four 4 hours; the dark blue formazan product formed by the cells was dissolved in DMSO under a safety cabinet and read at $550 \mathrm{~nm}$. Percentage inhibition were calculated and plotted with the concentrations and $\mathrm{Graph}$ (4.42 version) software used to calculate the $\mathrm{IC}_{50}$ values. ${ }^{11}$

Dye exclusion methods are traditionally used to assess cell viability, with trypan blue being one of the most common. Trypan blue is a vital stain leaves non- viable cells with a distinctive blue colour when observed under microscope, while viable cells have intact cell membrane and hence do not take in dye from the surrounding medium. On the other hand, non-viable cells do not have an intact and functional membrane and hence do take up dye from their surroundings. This results in the ability to easily distinguish between viable and non-viable cells, since the former are unstained, small, and round, while the latter are stained and swollen. ${ }^{12}$

Cell suspensions were prepared by incubating for 24 hours in $50 \% \mathrm{CO}_{2} 300 \mu \mathrm{l}$ of extract were added. After incubating for 48 hours, $100 \mu \mathrm{l}$ of cell suspension and $100 \mu \mathrm{l}$ of $0.4 \%$ Trypan blue solution were taken in an ependorf tube, mixed thoroughly and allowed to stand for $15 \mathrm{~min}$. Cover slip was placed and Pasteur pipette was used to transfer a small amount of Trypan blue- cell suspension Mixture to both chambers of a hemocytometer. The edge of the cover slip was carefully touched with the pipette tip and allowed each chamber to fill by capillary action. Starting with a chamber of the hemocytometer all the cells in the $1 \mathrm{~mm}$ center square and four $1 \mathrm{~mm}$ corner squares were counted and percentage inhibition was calculated and plotted with concentrations and Graph (5.0 version) software to calculate $\mathrm{IC}_{50}$ values. 


\section{International Journal of Current Science Research and Review}

ISSN: 2581-8341

Volume 04 Issue 08 August 2021

DOI: 10.47191/ijcsrr/V4-i8-18, Impact Factor: 5.825

IJCSRR@ 2021

WwW.ijcsrr.org

In-vivo Anti-tumor activity

Dalton's Ascites Lymphoma cells induced anti-tumor study

$\begin{array}{ll}\text { Group I } & \text { Normal control (Oral dose of } 10 \mathrm{ml} / \mathrm{kg}) \text { Sodium CMC suspension }(0.5 \%) \\ \text { Group II } & \text { DAL control (Oral dose of } 10 \mathrm{ml} / \mathrm{kg}) \text { Sodium CMC suspension }(0.5 \%) \\ \text { Group III } & \text { DAL induced +5-FU (Oral dose of } 20 \mathrm{mg} / \mathrm{kg}) \\ \text { Group IV } & \text { DAL induced + Ethanolic extract }(200 \mathrm{mg} / \mathrm{kg}) \text { treated mice } \\ \text { Group V } & \text { DAL induced + Ethanolic extract }(400 \mathrm{mg} / \mathrm{kg}) \text { treated mice }\end{array}$

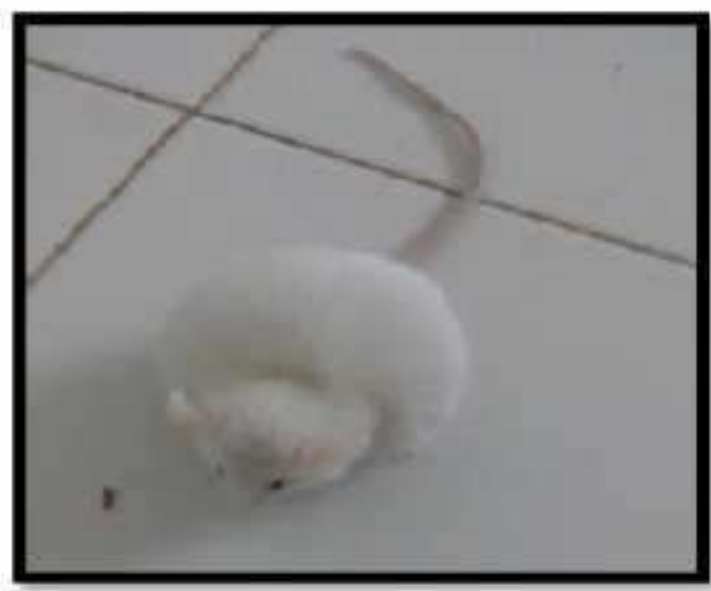

Fig 2. Tumour bearing mice

Thirty mice were divided into 5 groups, Each group containing 6 animals, Respectively, all the treatments are given orally at 24 hours after tumour inoculation and continued once daily for 14 days. On the $15^{\text {th }}$ day, half of the animals from each group are anesthetized and blood is collected by retro-orbital puncture for the evaluation of haematological parameters, which include Haemoglobin (Hb) content, Red Blood cell count (RBC) and White Blood Cell count (WBC). The remaining animals in each of the groups are kept to check the Mean Survival

Time (MST) and percent increase in life span of the tumour bearing hosts. ${ }^{13}$

\section{Tumor growth response}

Anti-tumor effect of the extract will be assessed by observation of change with respect of body weight, ascetic tumour volume and viable tumour cell count, Mean Survival Time ( MST) and percentage increase in life span (\%ILS).

\section{Tumor cell volume}

The mice will be dissected for collecting ascetic fluid from peritoneal cavity. The transplantable murine tumor will be carefully collected and measure the fluid volume.

\section{Viable and non-viable cell count}

Viable and non-viable cell counting of ascitic cells will be performed by dye exclusion test using Trypan blue stain $(0.4 \%$ in normal saline). The cell counts will be determined in a Neubauer counting chamber.

\section{Mean Survival Time (MST) and percent increase in life span}

The effect of extract on tumor growth will be observed by MST and \%ILS. MST of each group containing 6 mice will be monitored by recording the mortality daily for 6 weeks and \%ILS was calculated by by using following equation.

$$
\text { Death MST }=\frac{\text { Day of first death }+ \text { Day of last death }}{2}
$$




\section{International Journal of Current Science Research and Review}

ISSN: 2581-8341

Volume 04 Issue 08 August 2021

DOI: 10.47191/ijcsrr/V4-i8-18, Impact Factor: 5.825

IJCSRR@ 2021

WwW.ijcsrr.org

\section{In-vitro Anti-oxidant study}

Anti-oxidant are the substances which inhibit oxidation, which have the ability to remove the potentially damaging oxidizing agents in a living organism. Free radicals are highly reactive compounds, they are chemical species associated with an odd or unpaired electron and can be formed when oxygen interacts with certain molecules. They are neutral, short lived, unstable and highly reactive to pair with the odd electron and finally achieve stable configuration. There are many possibilities and understandings have recently leaded to a great increase in interest in natural antioxidant of plant origin.

\section{Nitric Oxide Free Radical Scavenging Activity}

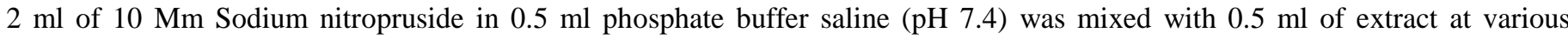
concentrations and the mixture incubated at $25^{\circ} \mathrm{C}$ for $150 \mathrm{~min}$. From the incubated mixture $0.5 \mathrm{ml}$ was taken out and added into 1.0 $\mathrm{ml}$ sulphanilic acid reagent (33\% in $20 \%$ glacial acetic acid) and incubated at room temperature for 5 min. Finally, $1.0 \mathrm{ml}$ naphthyl ethylenediamine dihydrochloride, $(0.1 \% \mathrm{w} / \mathrm{v})$ was mixed and incubated at room temperature for 30 min before measuring the absorbance at $540 \mathrm{~nm}$ was measured with a spectrophotometer. The nitric oxide radical scavenging activity was calculated. ${ }^{14}$

\section{$\mathrm{S} \%=[$ (A control - A sample $) /$ A control $] \times 100$}

Where $\mathrm{A}_{\text {control }}$ absorbance of the blank control (containing all reagents except the extract solution) and $\mathrm{A}_{\text {sample }}=$ absorbance of test sample.

\section{DPPH Assay}

Step 1 ( Preparation of stock solution )

Prepare $0.05 \mathrm{Mm}$ solution of DPPH by mixing $9.8 \mathrm{mg}$ of DPPH in $50 \mathrm{ml}$ ethanol and incubate it at normal room temperature for 23 hours.

Step 2 ( Preparation of Drug dilution )

Stock solution of $1 \mathrm{mg} / \mathrm{ml}$ of the plant extract is prepared in distilled water and diluted to get various concentration.

Step 3 (Reaction mixture and analysis)

a) Working solution: Take out $10 \mathrm{ml}$ of stock solution and dissolve it in $40 \mathrm{ml}$ of ethanol.

This makes the working solution.

b) Reaction mixture: Mix $1 \mathrm{ml}$ of working solution with $1 \mathrm{ml}$ various extract concentration $(100-1000 \mu \mathrm{g} / \mathrm{ml})$.

Prepare in final volume of $1 \mathrm{ml}$ incubate the mixture for $30 \mathrm{~min}$ at room temperature. After 20 min absorbance, reaction mixture was recorded at $517 \mathrm{~nm}$. Reference compound used here was Ascorbic acid. All the tests were performed in triplicate in order to get the mean values. The percentage inhibition was calculated by comparing the absorbance values of the control and test samples. Antioxidant activity was expressed as percentage inhibition (I \%) and calculated using the following equation. ${ }^{\mathbf{1 5}, \mathbf{1 6}}$

Percentage inhibition $(\mathbf{I} \%)=\left(\mathbf{A b s}_{\text {control- }}\right.$ Abssample/ Abscontrol $)$

\section{Statistical analysis}

The experimental results will be expressed as mean+ SEM. Data is assessed by ANOVA followed by the Tukey tests. Value of $\mathrm{p}<$ 0.05 was considered as statistically significant. The $\mathrm{IC}_{50}$ concentration were calculated using Graph software (5.0).The statistical analysis will be performed using Instat (7.0).

\section{RESULTS AND DISCUSSION}

\section{Acute oral toxicity study}

- No mortality at a dose of $2000 \mathrm{mg} / \mathrm{kg}$

- All the animals were found to be normal

- No behavioural changes were found on animal till the end of testing.

- No observable differences in body weight till the end of testing the extract was found to safe up to $2000 \mathrm{mg} / \mathrm{kg}$.

- From the study $1 / 5$ th and $1 / 10$ th of $2000 \mathrm{mg} / \mathrm{kg}$ of ethanol extract were selected for further pharmacological screening. As shown in Fig:3 


\section{International Journal of Current Science Research and Review}

ISSN: 2581-8341

Volume 04 Issue 08 August 2021

DOI: 10.47191/ijcsrr/V4-i8-18, Impact Factor: 5.825

IJCSRR@ 2021

www.ijesrr.org

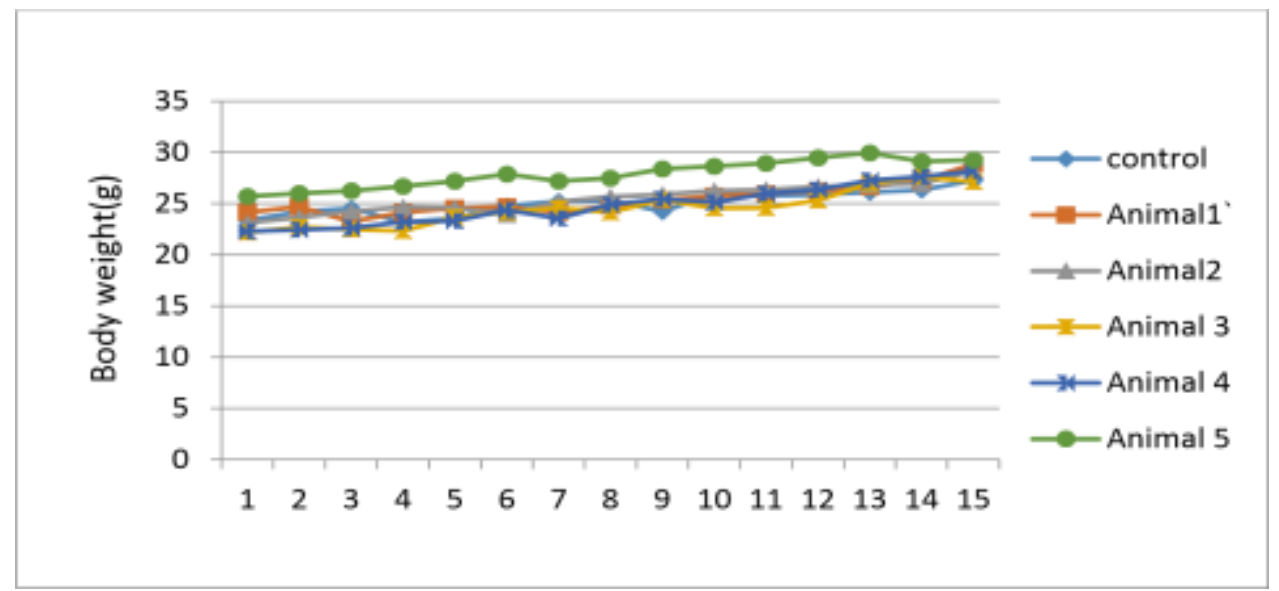

Fig 3. Body weight changes of EEEA in Acute oral toxicity study

\section{In-vitro anti-tumor activity}

The in-vitro anti-tumor activity against DAL cell lines were carried out for EEEA at different concentrations to determine the $\mathrm{IC}_{50}$ (50\% growth inhibition) by MTT assay and Trypan blue dye exclusion assay.

\section{MTT assay}

As per the MTT assay in DAL cell line, the percentage inhibition increased in a dose dependent manner. 5-FU inhibits the process $(50 \%)$ at a concentration of $55.60 \mu \mathrm{g} / \mathrm{ml}$. At the same extend the EEEA inhibit the process at $140.95 \mu \mathrm{g} / \mathrm{ml}$ (Table 1). It indicates that the EEEA possess better cytotoxic effect ( Fig 4).

Table 1. Percentage inhibition of EEEA

\begin{tabular}{|c|c|c|c|c|c|c|c|}
\hline \multirow{3}{*}{ Cell line } & \multirow[t]{3}{*}{ Samples } & \multicolumn{5}{|l|}{$\%$ inhibition } & \multirow[t]{3}{*}{ IC50 $(\mu \mathrm{g} / \mathrm{ml})$} \\
\hline & & \multicolumn{5}{|c|}{ Concentration $(\mu \mathrm{g} / \mathrm{ml})$} & \\
\hline & & 10 & 20 & 50 & 100 & 200 & \\
\hline \multirow{2}{*}{$\begin{array}{r}\text { DAL } \\
\text { cell line }\end{array}$} & 5-FU & $22.07 \pm 0.021$ & $30.76 \pm 0.042$ & $56.01 \pm 0.012$ & $81.39 \pm 0.562$ & $86.99 \pm 0.11$ & 55.60 \\
\hline & EEEA & $9.87 \pm 0.287$ & $15.25 \pm 0.352$ & $22.89 \pm 0.34$ & $40.01 \pm 0.328$ & $58.24 \pm 0.329$ & 140.95 \\
\hline
\end{tabular}

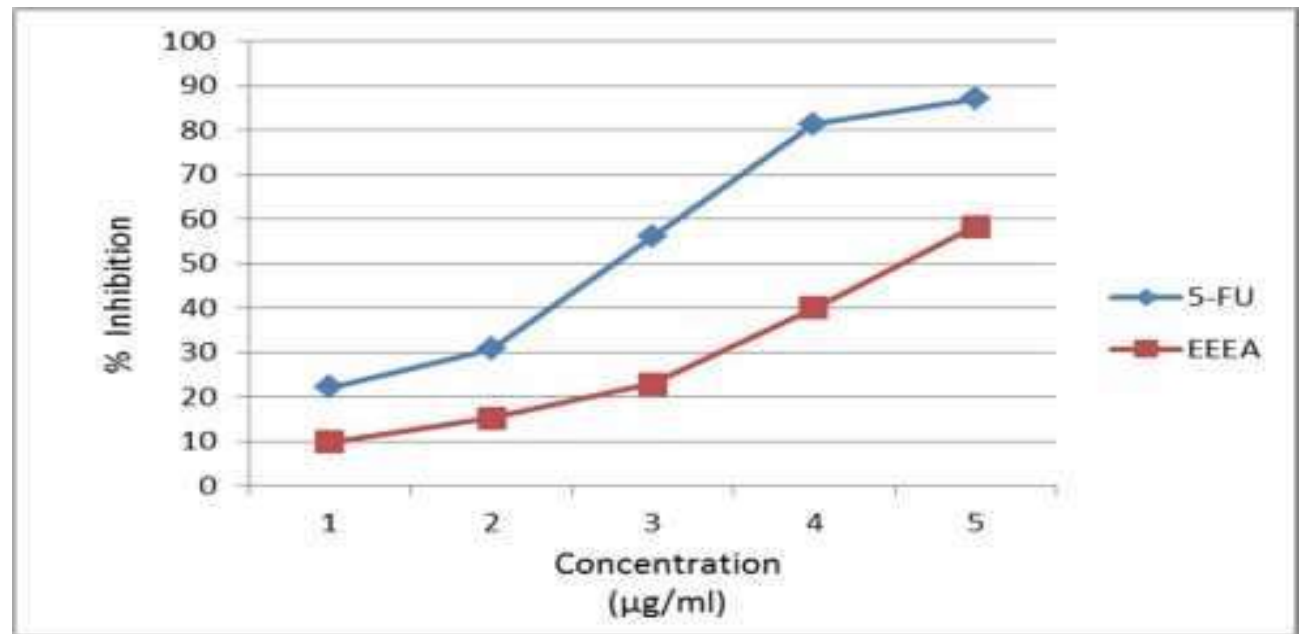

Fig 4. Concentration Vs \% inhibition graph showing effect on DAL cell line 


\section{International Journal of Current Science Research and Review}

ISSN: 2581-8341

Volume 04 Issue 08 August 2021

DOI: 10.47191/ijcsrr/V4-i8-18, Impact Factor: 5.825

IJCSRR@ 2021

www.ijesrr.org

Trypan blue dye exclusion assay

As per the Trypan blue dye exclusion assay. In DAL cell line, at a concentration of $55.72 \mu \mathrm{g} / \mathrm{ml} 5$-FU inhibit the process. At the same time EEEA inhibit at a concentration of $158.89 \mu \mathrm{g} / \mathrm{ml}$ (Table 2). So the both in-vitro study indicate that EEEA possess cytotoxic effect and EEEA may contain potential compounds or active principles which render the plants with anticancer proliferative activities (Fig 5). ${ }^{17}$

Table 2. Percentage inhibition of EEEA

\begin{tabular}{|c|c|c|c|c|c|c|c|}
\hline \multirow[t]{3}{*}{ Cell line } & \multirow[t]{3}{*}{ Samples } & \multicolumn{5}{|l|}{$\%$ inhibition } & \multirow[t]{3}{*}{$\operatorname{IC50}(\mu \mathrm{g} / \mathrm{ml})$} \\
\hline & & \multicolumn{5}{|c|}{ Concentration $(\mu \mathrm{g} / \mathrm{ml})$} & \\
\hline & & 10 & 20 & 50 & 100 & 200 & \\
\hline \multirow{2}{*}{$\begin{array}{l}\text { DAL cell } \\
\text { line }\end{array}$} & 5-FU & $22.07 \pm 0.021$ & $30.76 \pm 0.042$ & $56.01 \pm 0.012$ & $81.39 \pm 0.562$ & $86.99 \pm 0.011$ & 55.72 \\
\hline & EEEA & $10.1 \pm 0.021$ & $15.06 \pm 0.034$ & $23.03 \pm 0.018$ & $40 \pm 0.037$ & $58 \pm 0.001$ & 158.89 \\
\hline
\end{tabular}

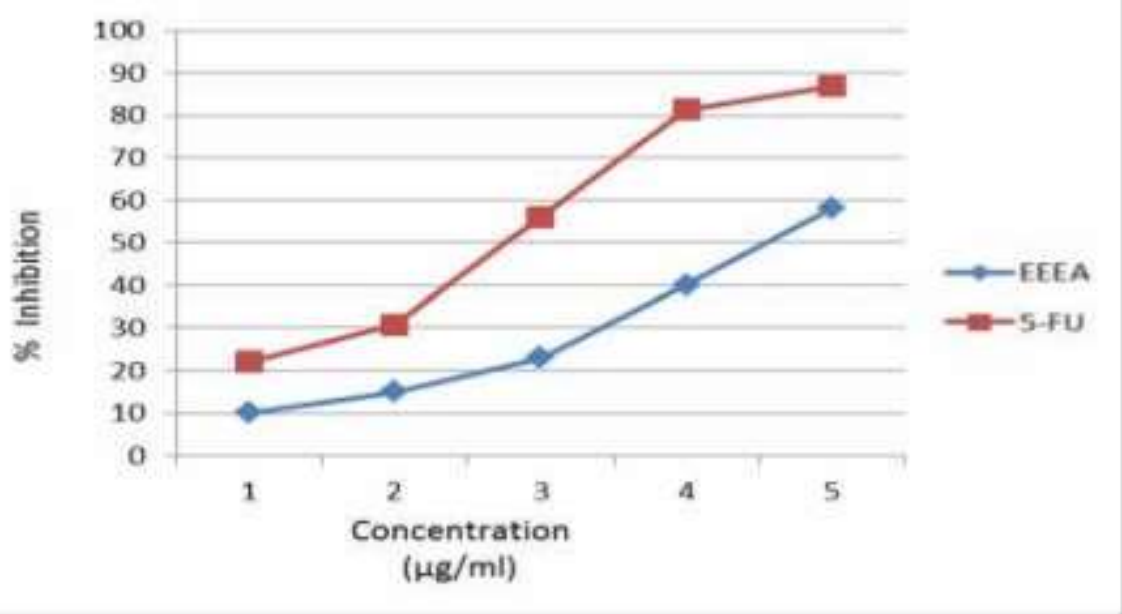

Fig 5. Concentration Vs \% inhibition graph showing effect on DAL cell line

\section{In-vivo Anti-tumor activity}

\section{DAL Tumor model}

The in-vivo anti-tumor activity against DAL cell lines was carried out for EEEA. Various haematological and other parameters were determined through this study.

The body weight of the animals indicated the health status during the period of study. The normal control possess no significant variations during the period of studies (Table 3). There is a significant increase in the body weight in the DAL tumor bearing mice due to the rapid increase in ascetic tumor volume (Fig 6). The EEEA treated tumour bearing significantly prevented the increase in body weight that was observed in DAL control mice.

Table 3.Effect of body weight

\begin{tabular}{|l|l|l|l|l|l|}
\hline Parameter & $\begin{array}{c}\text { Normal } \\
\text { Control }\end{array}$ & $\begin{array}{l}\text { DAL } \\
\text { Control }\end{array}$ & $\begin{array}{l}\mathbf{5 - F U} \\
\mathbf{2 0} \mathbf{~ m g} / \mathbf{k g}\end{array}$ & $\begin{array}{l}\text { EEEA } \\
\mathbf{2 0 0} \mathbf{~ m g} / \mathbf{k g}\end{array}$ & $\begin{array}{c}\text { EEEA } \\
\mathbf{4 0 0} \mathbf{~ m g} / \mathbf{k g}\end{array}$ \\
\hline $\begin{array}{c}\text { Body } \\
\text { weight }(\mathrm{g})\end{array}$ & $27.96 \pm 0.391$ & $40.53 \pm 0.836^{* * *}$ & $32.70 \pm 0.827 * * *$ & $37.52 \pm 1.208 \mathrm{~ns}$ & $35.46 \pm 0.67 * * *$ \\
\hline
\end{tabular}

Values are mean SEM; $(n=6) ; * * * p<0.001$ - normal compared with EAC control, $* * p<0.01, * p<0.05$ other groups compared with EAC control. 


\section{International Journal of Current Science Research and Review}

ISSN: 2581-8341

Volume 04 Issue 08 August 2021

DOI: 10.47191/ijesrr/V4-i8-18, Impact Factor: 5.825

IJCSRR @ 2021

www.ijesrr.org

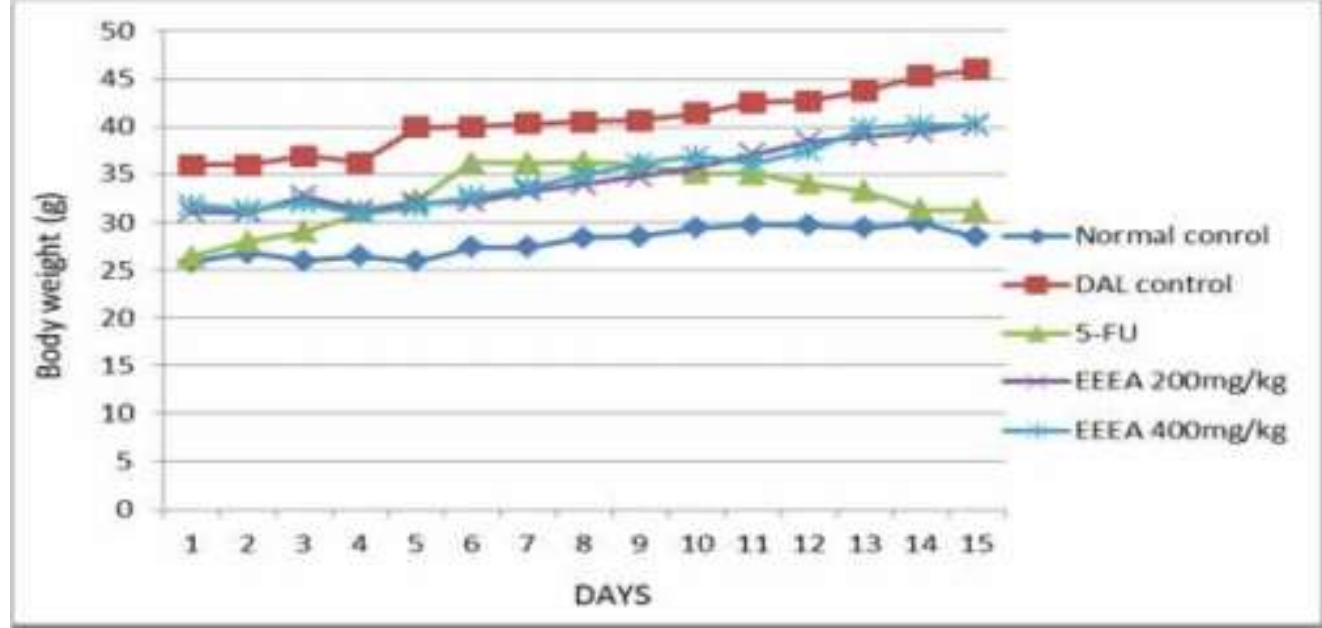

Fig 6. Effect of body weight

Effect of haematological parameters in DAL induced in-vivo anti-tumor activity

On $15^{\text {th }}$ day half of the animals were subjected to the analysis of the haematological parameters. Animals were anaesthetized and blood was collected by using Neubauer counting chamber. Haemometer used for measuring the Hb level in mice.

Normal control group showed a normal range of WBC, RBC and Hb levels, (Table 4). While DAL tumour bearing mice showed a significant decrease in RBC (Fig 7), Hb (Fig 9) and significant increase in WBC levels (Fig 8). Treatment with EEEA significantly reversed DAL induced tumor, changes in haematological profiles.

Treatment with EEEA restored the haematological profile as compared to DAL mice. This indicates EEEA possess protective action on the haemopoietic system.

Table 4. Effect of haematological parametrs

\begin{tabular}{|l|l|l|l|l|l|}
\hline Parameter & Normal control & DAL control & $\mathbf{5 - F U ~ 2 0 ~} \mathbf{~ g g} / \mathbf{k g}$ & EEEA 200 mg/kg & EEEA 400 mg/kg \\
\hline $\mathrm{WBC}$ & $8743.5 \pm 14.841 * * *$ & $25779.83 \pm 8.336 * * *$ & $1178.5 \pm 1.566 * * *$ & $20352.6 \pm 19.768 * * *$ & $13115 \pm 59.32 * * *$ \\
\hline $\mathrm{RBC}$ & $8.85 \pm 0.062$ & $3.583 \pm 0.038 * * *$ & $8.035 \pm 0.07201 * * *$ & $6.59 \pm 0.1539 * * *$ & $6.5933 \pm 0.1257 * * *$ \\
\hline $\mathrm{Hb}$ & $14.68 \pm 0.081$ & $6.101 \pm 0.030 * * *$ & $15.23 \pm 0.0410 * * *$ & $12.77 \pm 0.096 * * *$ & $8.745 \pm 0.0534 * * *$ \\
\hline
\end{tabular}

Values are mean \pm SEM $(\mathrm{n}=6) ; * * * \mathrm{p}<0.001$ normal compared with DAL control

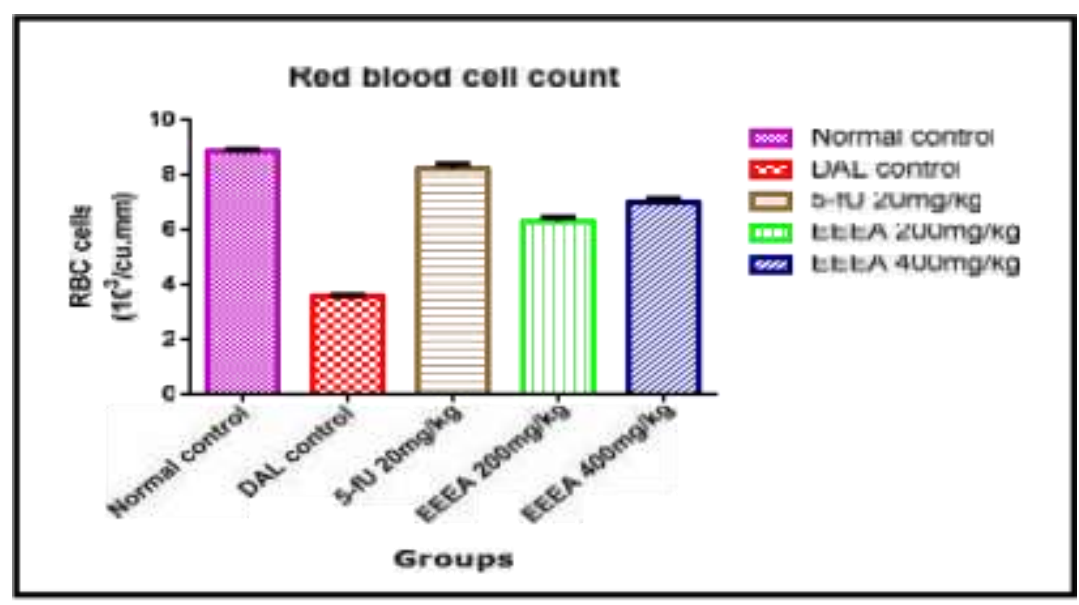

Fig 7. Effect of RBC count 


\section{International Journal of Current Science Research and Review}

ISSN: 2581-8341

Volume 04 Issue 08 August 2021

DOI: 10.47191/ijesrr/V4-i8-18, Impact Factor: 5.825

IJCSRR@ 2021

www.ijcsrr.org

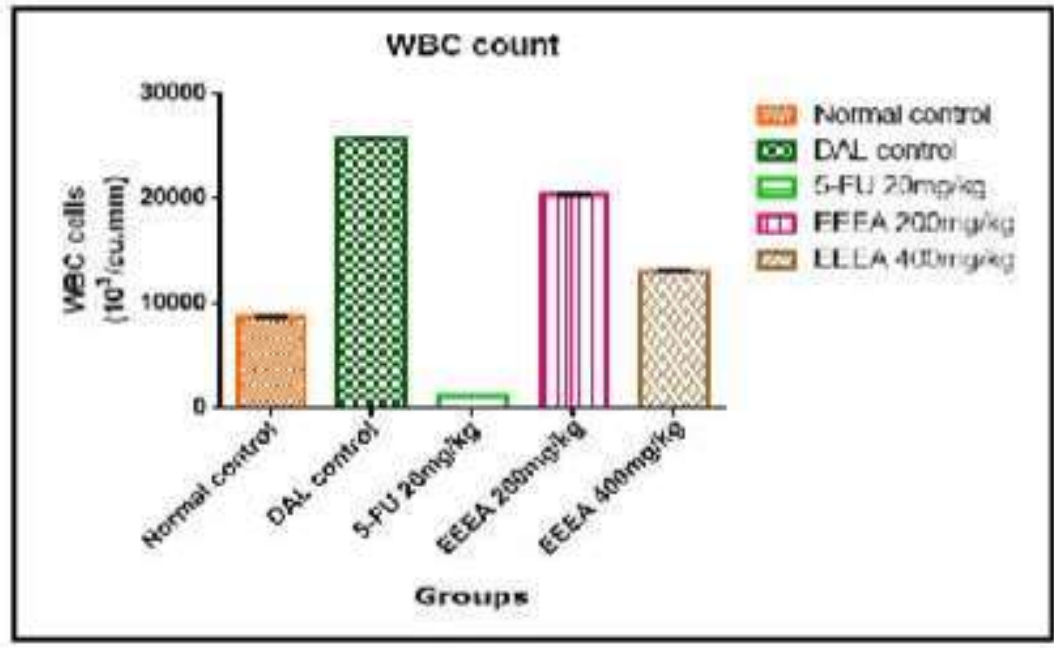

Fig 8. Effect of WBC count.

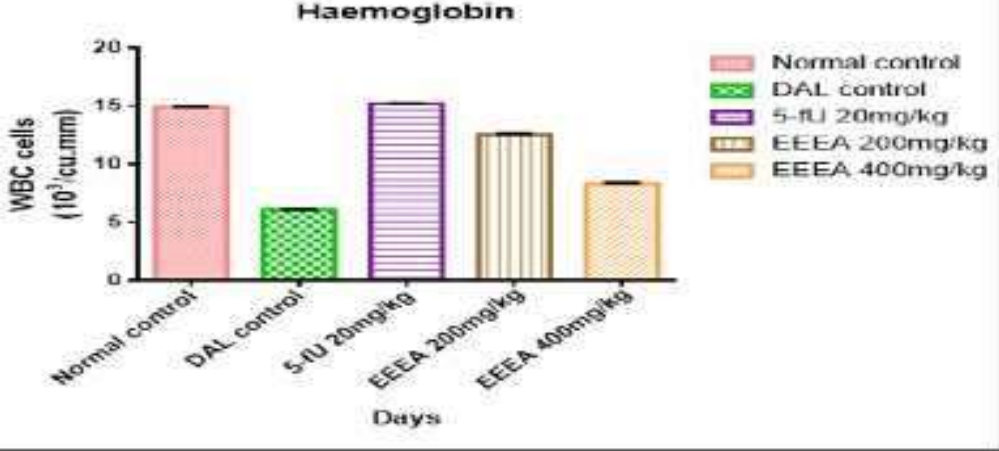

Fig 9. Effect of $\mathrm{Hb}$ Level Effect of tumor weight and tumor volume in in-vivo anti-cancer study

After analyzing the haematological parameters, the mice were weighed and sacrificed. The mice will be dissected for collecting ascetic fluid from peritoneal cavity. The transplantable murine tumour will be carefully collected and measured the volume called tumour volume. After that again weighed the dead animal and subtracted from the previous weight, resulted the tumor weight of the animals. There is a significant increase in the tumor weight and tumor volume in the DAL tumor bearing mice indicates that rapid increase in the ascetic tumor volume (Table 5). The EEEA showed a significant decrease in tumor weight ( Fig 10) as well as tumour volume (Fig 11). This will indicate that the samples which having a preventive effect in the proliferation of ascetic tumor growth.

Table 5. Effect of tumor weight and tumor volume

\begin{tabular}{|l|l|l|l|l|}
\hline Parameter & DAL control & 5-FU 20 mg/kg & EEEA 200 mg/kg & EEEA400 mg/kg \\
\hline $\begin{array}{l}\text { Tumour } \\
\text { weight }(\mathrm{g})\end{array}$ & $23.08 \pm 0.582$ & $8.8 \pm 0.435^{* * *}$ & $18.33 \pm 0.1940^{* * *}$ & $15.28 \pm 0.1069^{* * *}$ \\
\hline $\begin{array}{l}\text { Tumour } \\
\text { volume (ml) }\end{array}$ & $19.80 \pm 0.341$ & $7.89 \pm 0.035^{* * * *}$ & $15.2233 \pm 0.0554 * * *$ & $15.7466 \pm 0.2041^{* * *}$ \\
\hline
\end{tabular}

Values are mean \pm SEM $(\mathrm{n}=6) ; * * * \mathrm{p}<0.001$-Normal compared with DAL control 


\section{International Journal of Current Science Research and Review}

ISSN: 2581-8341

Volume 04 Issue 08 August 2021

DOI: 10.47191/ijesrr/V4-i8-18, Impact Factor: 5.825

IJCSRR@ 2021

www.ijesrr.org
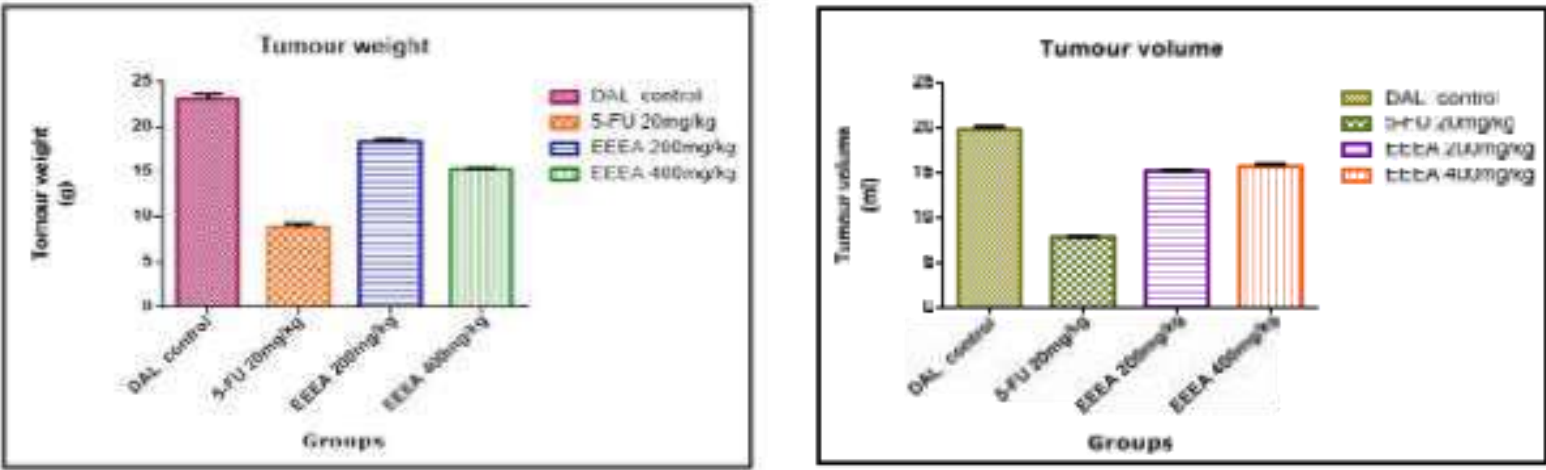

Fig $10 \& 11$ Effect of Tumor weight and Tumor volume

\section{Effect of viable cell count and non-viable cell count}

Viable and non- viable cell counting of ascitic cells will be performed by dye exclusion test using Trypan blue stain (0.4\% in normal saline). The cell counts will be determined in a Neubauer counting chamber (Table 6).The DAL tumor bearing mice possess significant increase in the viable cell( Fig 12 ) count and significant decrease in the non- viable cell count( Fig 13 ). This will indicate the proliferation of tumor cells in the mice but the EEEA treated group mice possess significant decrease in the viable cell count and increase in the non- viable cell count. These results indicated that the EEEA possess good cytotoxic effect as well as the anticancer nature against DAL cell line.

Table 6. Effect of viable cell count and non-viable cell count

\begin{tabular}{|c|c|c|c|c|}
\hline Parameter & DAL control & $\begin{array}{l}5-\mathrm{FU} \\
20 \mathrm{mg} / \mathrm{kg}\end{array}$ & $\begin{array}{l}\text { EEEA } \\
200 \mathrm{mg} / \mathrm{kg}\end{array}$ & $\begin{array}{l}\text { EEEA } \\
400 \mathrm{mg} / \mathrm{kg}\end{array}$ \\
\hline $\begin{array}{l}\text { Viable cells } \\
\left(\mathrm{x} 10^{7} \text { cells } \mathrm{ml}-1\right)\end{array}$ & $9.71 \pm 0.0175$ & $8.81 \pm 0.059 * * *$ & $4.4683 \pm 0.09453 * * *$ & $4.045 \pm 0.04603 * * *$ \\
\hline $\begin{array}{l}\text { Non-Viable Cells } \\
\left(\mathrm{x} 10^{7} \text { cells ml-1) }\right.\end{array}$ & $0.815 \pm 0.007$ & $5.61 \pm 0.0493 * * *$ & $4.435 \pm 0.06015 * * *$ & $3.4033 \pm 0.01313^{* * *}$ \\
\hline
\end{tabular}

Values are mean \pm SEM $(n=6) ; * * * p<0.001$ normal compared with DAL control.
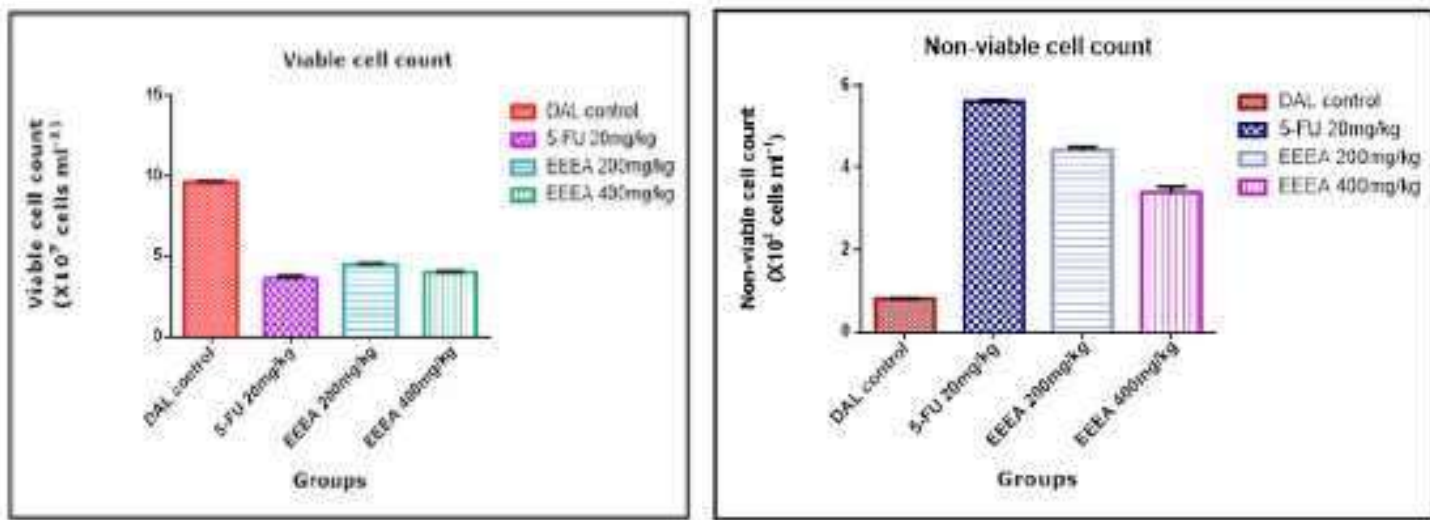

Fig 12 \&13. Effect of viable cell and Non-viable cell count 


\section{International Journal of Current Science Research and Review}

ISSN: 2581-8341

Volume 04 Issue 08 August 2021

DOI: 10.47191/ijcsrr/V4-i8-18, Impact Factor: 5.825

IJCSRR@ 2021

Www.ijesrr.org

\section{Effect of mean survival time and percentage increasing life span}

In DAL tumor control group, the survival time of animals was found to be 21 days. The reliable criteria for judging the potency of an anti-tumor drug is the prolongation of the life span of tumor bearing animals. The mice bearing DAL tumor when orally administered with EEEA showed a significant increase in the life span and also a significantly prevented the increase in body weight that was observing in the DAL control mice (Table 7). It will indicate the anti-tumor nature of EEEA.

Table 7. Effect of survival time of tumor bearing mice

\begin{tabular}{|l|l|l|l|l|}
\hline \multicolumn{1}{|c|}{ Parameter } & DAL control & 5-FU 20 $\mathbf{~ m g} / \mathbf{k g}$ & EEEA 200 $\mathbf{~ m g} / \mathbf{k g}$ & EEEA 400 $\mathbf{~ m g / k g}$ \\
\hline $\begin{array}{l}\text { Mean survival } \\
\text { time }\end{array}$ & 21 days & 28 days & 22 days & 24 days \\
\hline $\begin{array}{l}\text { Percentage life } \\
\text { Span }\end{array}$ & - & $33.33 \%$ & $8.62 \%$ & $18.64 \%$ \\
\hline
\end{tabular}

\section{In-vitro Anti-oxidant study}

\section{Nitric Oxide Free Radical Scavenging Activity}

EEEA significantly inhibited nitric oxide in a dose dependent manner. The results indicated that the extract might contain compounds able to inhibit to nitric oxide (Fig 14). The $\mathrm{IC}_{50}$ values for EEEA and Ascorbic acid were found to be $48.65 \mu \mathrm{g} / \mathrm{ml}$ and $69.17 \mu \mathrm{g} / \mathrm{ml}$ respectively (Table 8).

Table 8. Percentage inhibition and $\mathrm{IC}_{50}$ values

\begin{tabular}{|c|c|c|c|c|c|c|}
\hline \multirow{2}{*}{ Sl No. } & \multirow{2}{*}{$\begin{array}{l}\text { Concentration } \\
(\mu \mathrm{g} / \mathrm{ml})\end{array}$} & \multicolumn{3}{|c|}{ Absorbance } & \multirow{3}{*}{$\begin{array}{c}\text { \%inhibition } \\
(\text { mean } \pm \text { SD) }\end{array}$} & \multirow{3}{*}{$\begin{array}{l}\text { IC50 } \\
\mu \mathrm{g} / \mathrm{ml})\end{array}$} \\
\hline & & 1 & 2 & 3 & & \\
\hline 1 & Control blank & \multicolumn{3}{|l|}{1.4102} & & \\
\hline \multicolumn{7}{|c|}{ Standa rd Ascorbi c acid } \\
\hline 1 & 12.5 & 1.0925 & 1.0971 & 1.1190 & $21.85 \pm 0.1452$ & \multirow{4}{*}{48.65} \\
\hline 2 & 25 & 0.8730 & 0.7989 & 0.7996 & $41.57 \pm 0.317$ & \\
\hline 3 & 50 & 0.6193 & 0.6174 & 0.6084 & $69.47 \pm 0.088$ & \\
\hline 4 & 100 & 0.3298 & 0.3421 & 0.3347 & $86.94 \pm 0.043$ & \\
\hline \multicolumn{7}{|c|}{ EEEA } \\
\hline 1 & 50 & 0.6821 & 0.7215 & 0.7216 & $45.81 \pm 0.021$ & \multirow{4}{*}{69.17} \\
\hline 2 & 100 & 0.5241 & 0.5427 & 0.5241 & $58.02 \pm 0.032$ & \\
\hline 3 & 150 & 0.3987 & 0.4521 & 0.4421 & $69.47 \pm 0.0888$ & \\
\hline 4 & 200 & 0.1682 & 0.1621 & 0.1565 & $86.93 \pm 0.020$ & \\
\hline
\end{tabular}




\section{International Journal of Current Science Research and Review}

ISSN: 2581-8341

Volume 04 Issue 08 August 2021

DOI: 10.47191/ijcsrr/V4-i8-18, Impact Factor: 5.825

IJCSRR@ 2021

www.ijcsrr.org

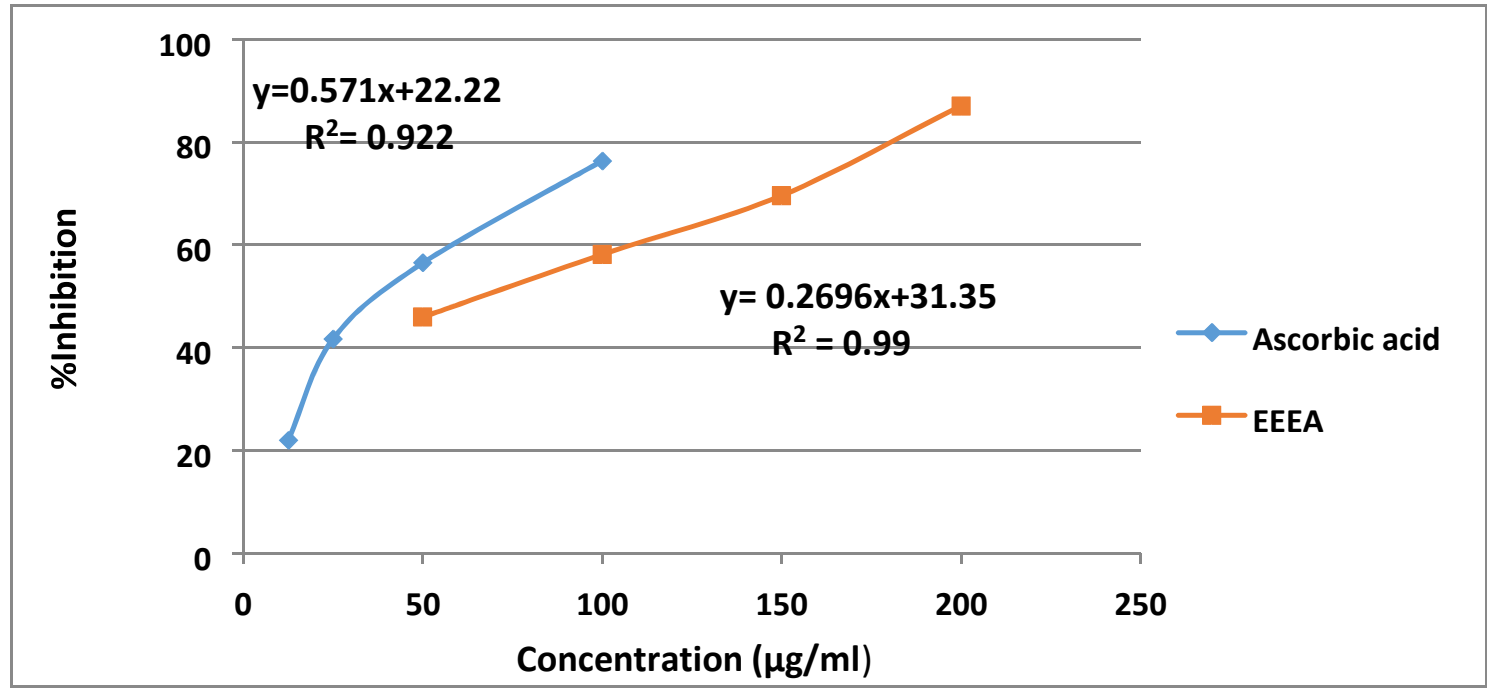

Fig 14. Nitric Oxide Free Radical Scavenging Activity

\section{DPPH Assay}

EEEA significantly inhibited DPPH in a dose dependent manner. The results indicated that the extract might contain compounds able to inhibit to DPPH (Fig 15). The $\mathrm{IC}_{50}$ values for EEEA and Ascorbic acid were found to be $54.03 \mu \mathrm{g} / \mathrm{ml}$ and $113.98 \mu \mathrm{g} / \mathrm{ml}$ respectively (Table

9).

Table 9. Percentage inhibition and $\mathrm{IC}_{50}$ values

\begin{tabular}{|c|c|c|c|c|c|c|}
\hline \multirow{2}{*}{ Sl No. } & \multirow{2}{*}{$\begin{array}{l}\text { Concentration } \\
(\mu \mathrm{g} / \mathrm{ml})\end{array}$} & \multicolumn{3}{|c|}{ Absorbance } & \multirow{3}{*}{$\begin{array}{l}\text { \%inhibition } \\
(\text { mean } \pm \text { SD) }\end{array}$} & \multirow{3}{*}{$\begin{array}{l}\text { IC50 } \\
\mu \mathrm{g} / \mathrm{ml})\end{array}$} \\
\hline & & 1 & 2 & 3 & & \\
\hline 1 & Control blank & \multicolumn{3}{|l|}{1.3042} & & \\
\hline \multicolumn{7}{|c|}{ Stand ard ascorbi $\mathrm{c}$ acid } \\
\hline 1 & 12.5 & 1.0772 & 1.0743 & 1.0724 & $18.23 \pm 0.483$ & \multirow{4}{*}{54.03} \\
\hline 2 & 25 & 0.8238 & 0.8146 & 0.8341 & $36.99 \pm 0.745$ & \\
\hline 3 & 50 & 0.6150 & 0.6278 & 0.6241 & $52.48 \pm 0.485$ & \\
\hline 4 & 100 & 0.3314 & 0.3302 & 0.3189 & $75.01 \pm 0.530$ & \\
\hline \multicolumn{7}{|c|}{ EEEA } \\
\hline 1 & 50 & 0.6821 & 0.7215 & 0.7216 & & \multirow{4}{*}{113.98} \\
\hline 2 & 100 & 0.5241 & 0.5427 & 0.5241 & & \\
\hline 3 & 150 & 0.3987 & 0.4521 & 0.4421 & & \\
\hline 4 & 200 & 0.1682 & 0.1621 & 0.1565 & & \\
\hline
\end{tabular}




\section{International Journal of Current Science Research and Review}

ISSN: 2581-8341

Volume 04 Issue 08 August 2021

DOI: 10.47191/ijesrr/V4-i8-18, Impact Factor: 5.825

IJCSRR@ 2021

www.ijcsrr.org

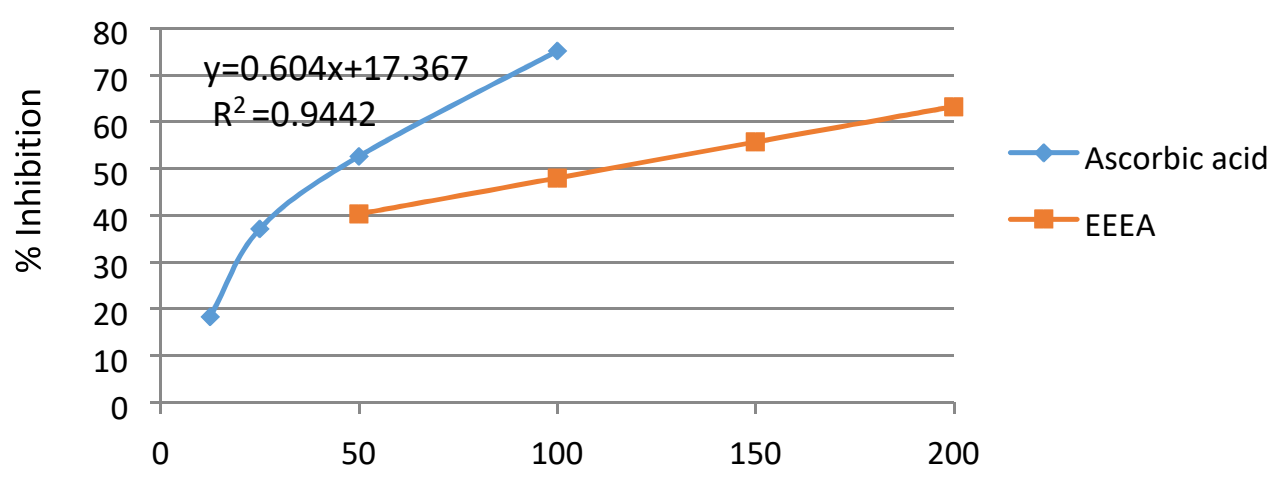

Fig 15. DPPH assay

\section{SUMMARY AND CONCLUSION}

The present study evaluated anti-tumor activity of Epipremnum aureum Linn. Leaves. The preliminary phytochemical screening of EEEA was performed and revealed the presence of flavanoids, glycosides, saponins, tannins, steroids, triterpeniods and carbohydrates. The acute toxicity study of ethanol extract was carried out as per OECD guidelines 425 . The results showed that there was no significant behavioural as well as weight changes in the animals. It can be concluded that the extract was safe up to a $2000 \mathrm{mg} / \mathrm{kg}$. EEEA was performed the invitro anti-oxidant studied by Nitric Oxide Scavenging Assay and DPPH assay. The results showed a significant anti-oxidant activity. EEEA was subjected in-vitro anti-tumor activity against DAL cell line by MTT assay and Trypan blue dye exclusion assay. The results suggested that EEEA showed moderate activity against cell line. EEEA showed good cytotoxic effect on DAL cell line in MTT assay and Trypan blue dye exclusion assay. EEEA showed significant reduction in the percent increase in body weight, tumour volume, tumour weight, viable cell count and increased non-viable cell count. These results suggested that Epipremnum aureum Linn. exhibit significant anti-tumor activity towards DAL cell line.

Further study is needed to isolate the active component responsible for its activity.

\section{ACKNOWLEDGEMENT}

The authors wish to thank the management of Devaki Amma Memorial College of Pharmacy, Chelembra, Malappuram, Kerala for encouraging and providing facilities.

\section{REFERENCES}

1. Saswati R, Dutta M and Paul S B. In vitro antibacterial activity of Alocasia decipiens schott, International Journal of Pharmacy and Pharmaceutical Sciences, 2013, 5(1), 155 - 57.

2. Chetan S S, Deepali M J, Sushama D P, Leena J P and Vilasrao J K. Phytochemical screening and in vitro anti-microbial activity studies of Epipremnum aureum Linn. leaves extracts, Der Pharmacia Sinica, 2011, 2(5), 267 - 72.

3. Chan M J and Turner I. M. The use of Epipremnum pinnatum (Araceae) in Singapore in the treatment of cancer: an unreported application of a herbal medicine, Economic Botany, 1998, 52(1), 108.

4. Srivasatava N, Shwarupa S and Bhagyawant S S. Comparative Study on the Anti Termite, Anti-microbial and Anti-oxidant Activity of Leaf and Root Extracts of Pothos Aurea, Journal of Pharmaceutical Research \& Clinical Practice, 2011, 1(2),1 $-11$.

5. Pandey M, Debnath M. Gupta S and Chikara S K. Phytomedicine: An ancient approach turning into future potential source of therapeutics, Journal of Pharmacognosy and phytotherapy, 2011, 3(1),113 - 17.

6. Palanisamy P, Jayakar B, Kumuthavalli M V, Kumar Y and Kashi S. Preliminary phytochemical evaluation of whole plant extract of Dipteracanthus prostrates nees, International research journal of pharmacy, 2012, 3(1), 150 - 53. 


\section{International Journal of Current Science Research and Review}

ISSN: 2581-8341

Volume 04 Issue 08 August 2021

DOI: 10.47191/ijesrr/V4-i8-18, Impact Factor: 5.825

IJCSRR@ 2021

www.ijcsrr.org

7. Kiran K S P, Sridevi V and Chandana L M V V. Studies on Phytochemical screening

of aqueous extract collected from fertilizers affected two medicinal plants, Journal of chemical, biological and physical science, 2012, 2(3), $1326-332$.

8. OECD (2001). Guidance document on the recognition, assessment and use of clinical signs as human end points for environmental animals use in safety evaluation. Environmental health and safety monograph series on the testing and assessment 24, 2001.

9. Hossain M A, Muhammad M D, Charles G, Muhammad I. In vitro total phenolics, flavonoids contents and anti-oxidant activity of essential oil, various organic extracts from the leaves of tropical medicinal plant Tetra stigma from Sabah. Asian Pacific Journal of Tropical Biomedicine, 2011, 4(9), 717 - 21.

10. Hung C Y, Sun Y H, Chen J, Darlington D E, Williams A and Burkey K O,Identification of a Mg protoporphyrin I Xmonomethyl ester cyclase homologue,

EaZIP, differentially expressed in variegated Epipremnum aureum 'Golden Pothos' is achieved through a unique method of comparative study using tissue regenerated plants. Journal of Experimental Botany, 2010, 61, 1483 - 93.

11. Leonard V M, Tungamirai M and John M B. Determination of ferulic acid and related compounds by thin layer chromatography, American Journal of Botany, 2006, 5(13), 1271 - 273.

12. Olubunmi A W and Anthony J A. Phytochemical constituents and antioxidant activities of the whole leaf extract of Aloe ferox Mill, Pharmacognosy magazine, 2011; 7(28):325 - 33.

13. Abbas $\mathrm{S}$ and Wink M. Epigallo catechin gallate from green tea (Camellia sinensis) increases lifespan and stress resistance in Caenorhabditis elegans. Planta Medica. 2009, 75, 216 - 21.

14. Dehshahri S, Wink M, Afsharypuor S, Asghari G and Mohagheghzadeh A. Antioxidant activity of methanolic leaf extract of Moringa peregrina (Forssk.) Fiori. Research in Pharmaceutical Sciences, 2012, 7(2), 111 - 18.

15. Hossain M A, A L-Raqmi K A, AL-Mijizy Z H, Weli A M and Al-Riyami Q. Study of total phenol, flavonoids contents and phytochemical screening of various leaves crude extracts of locally grown Thymus vulgaris, Asian Pacific Journal of Tropical and Biomedicine, 2013, 3(9),705 - 10.

16. Rosalind T H, Dutta B K, and Paul S B. Evaluation of in vitro antioxidant activity, estimation of total phenolic and flavonoid content of leaf extract of Eurya japonica Thunb. Asian Journal of Pharmaceutical and Clinical Research, 2013, 6(1), 152 -55 .

17. R.H. Liu, Potential synergy of phytochemicals in cancer prevention: Mechanism of action, Journal of Nutrition, 134, 2004, $3479 \mathrm{~S}-3485 \mathrm{~S}$.

Cite this Article: Venkatesh S., Muhamed K., Mridhul Mohan P., Asheena Asharaf V.V., Anjitha P., Suresh A. (2021). AntiTumor and Anti-Oxidant Activity of Ethanolic Extract of Epipremnum Aureum Linn. Leaves against DAL Induced Tumor in Swiss Albino Mice. International Journal of Current Science Research and Review, 4(8), 1008-1021 